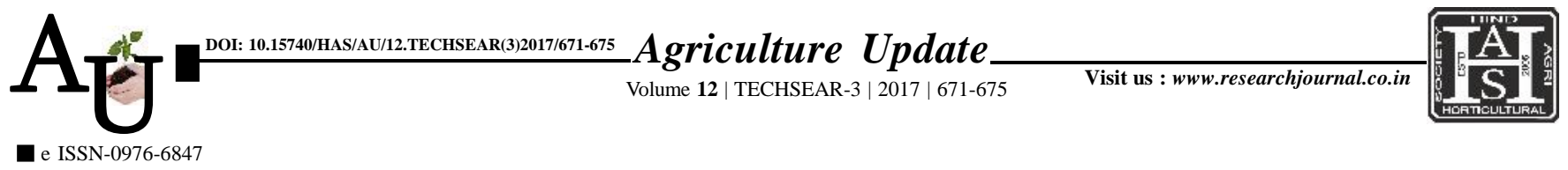

\title{
Research автіcle: Weed management for improvement in yield of aerobic rice
}

\author{
BIKAS CHANDRA PATRA, KORLA ADITYA CHOWDARY, MILAN KANTI \\ KUNDU AND G. SATHISH
}

Article Chronicle:

Received :

10.07.2017;

Accepted :

25.07.2017

KEY WoRDS :

Direct seeded rice, Propanil, Rice yield, Weed density, Weed control efficiency

Author for correspondence :

\section{BIKAS CHANDRA PATRA}

Department of

Agronomy, Bidhan

Chandra Krishi

Viswavidyalaya,

Mohanpur, NADIA (W.B.)

INDIA

Email : bikascpatra@

gmail.com

See end of the article for authors' affiliations
SUMMARY : Rice is a major food for more than half of the population in world and India. The changes in establishment methods like transplanted rice to direct seeded (aerobic) rice cultivation and chemical weed control instead of hand weeding are rising in most of the countries to reduce the cost of cultivation and consumption of irrigation water as the availability of labour and fresh water are decreasing day by day. Keeping these facts in view a field experiment was conducted to studyweed management practices impact on the improvement of yield of direct seeded rice at Instructional farm, BCKV, Mohanpur, West Bengal, India during Kharif, 2015 and 2016. The experimental results revealed lesser weed density in Propanil 35\% EC @ $3000 \mathrm{~g}$ a.i. ha ${ }^{-1}$ and recorded grain yield of $4.47 \mathrm{t} \mathrm{ha}^{-1}$ as compared to other herbicides namely oxyflourfen and cyhalofop butyl. Under the direct seeded condition Propani135\% EC @3000 g a.i. ha ${ }^{-1}$ can be recommended instead of laborious hand weeding without any harmful effects on growth and yield of rice.

How to cite this article : Patra, Bikas Chandra, Chowdary, Korla Aditya, Kundu, Milan Kanti and Sathish, G. (2017). Weed management for improvement in yield of aerobic rice. Agric. Update, 12(TECHSEAR-3) : 671-675; DOI: 10.15740/HAS/AU/12.TECHSEAR(3)2017/671-675. 